\title{
Bilateral clear lens extraction and intraocular lens implantation in a child with microspherophakia and Marfan syndrome
}

\section{Extração bilateral de cristalino transparente e implante de lente intraocular em criança com microesferofacia e síndrome de Marfan}

\author{
Joyce Godoy Farat', Marjorie Fornazier Nascimento Queiroz', Antonio Carlos Lottelli \\ 1. Department of Ophthalmology, Otorhinolaryngology and Head and Neck Surgery, Faculdade de Medicina de Botucatu, Universidade Estadual \\ Paulista "Julio de Mesquita Filho", Botucatu, SP, Brazil.
}

\begin{abstract}
We report the case of a 4-year-old boy with Marfan syndrome whose parents reported he had had low visual acuity since birth. On examination, there was microspherophakia and a small subluxation of the lens. The objective refraction was $-23.75-2.75 \times 70$ in the right eye and -25.50-3.50 x 90 in the left eye. Since the microspherophakia and the high myopia severely affected the boy's quality of life, clear lens extraction, anterior vitrectomy, posterior surgical capsulotomy via the pars plana, and intraocular lens implantation were performed. Two years postoperatively, the patient had centered intraocular lenses and a corrected visual acuity of 20/30 in both eyes. The child was satisfied with his vision and was able to study and perform daily activities without visual limitations.
\end{abstract}

Keywords: Marfan syndrome; Lens, intraocular; Lens implantation, intraocular; Lens, crystalline/surgery; Visual acuity; Humans; Child, preschool; Case reports

RESUMO | Reportamos o caso de um menino de 4 anos de idade com Síndrome de Marfan, cujos pais referiam que o mesmo apresentava baixa acuidade visual desde o nascimento. Ao exame oftalmológico, observou-se microesferofacia e discreta subluxação do cristalino bilateralmente. A refração estática era -23.75 - 2.75 x 70 no olho direito e -25.50 -3.50 x 90 no olho esquerdo. Como a microesferofacia e a alta miopia traziam sérios prejuízos à qualidade de vida do paciente, foi submetido à facoemulsificação de cristalino transparente, vitrectomia anterior, capsulotomia posterior via pars plana e implante de lente intrao-

Submitted for publication: April 22, 2018

Accepted for publication: June 22, 2018

Funding: No specific financial support was available for this study.

Disclosure of potential conflicts of interest: None of the authors have any potential conflicts of interest to disclose.

Corresponding author: Joyce Godoy Farat

Department of Ophthalmology, Otorhinolaryngology and Head and Neck Surgery,

Faculdade de Medicina de Botucatu. Universidade Estadual Paulista - Distrito de

Rubião Júnior, s/n 18618-970 - Botucatu, SP - 18618-970 - Brazil

E-mail: joycegodoyfarat@uol.com.br cular. Em seguimento pós-operatório de dois anos, mantinha lentes intraoculares centradas, eixo visual livre, acuidade visual corrigida de 20/30 em ambos os olhos. Paciente satisfeito com a visão podendo estudar e exercer todas as atividades do dia a dia sem limitações visuais.

Descritores: Síndrome de Marfan; Lentes intraoculares; Implante de lente intraocular; Cristalino/cirurgia; Acuidade visual; Humanos; Pré-escolar; Relatos de casos

\section{INTRODUCTION}

Microspherophakia is a rare lenticular abnormality characterized by bilateral spherophakia and microphakia. Lens dislocation or subluxation may occur, leading to defective accommodation ${ }^{(1)}$. Microspherophakia is often described in association with systemic diseases such as Marfan and Weill-Marchesani syndromes ${ }^{(2)}$. Phakic pupillary block glaucoma and high lenticular myopia are common complications. Glaucoma may be present in up to $51 \%$ of eyes and is the main complication that can lead to severe and permanent loss of vision ${ }^{(3)}$.

\section{CASE REPORT}

A 4-year-old Brazilian boy came to our institution accompanied by his parents, who reported that he had had low visual acuity since birth. He had been diagnosed with Marfan syndrome and cardiomyopathy, which was treated with systemic $\beta$-blockade. He was not able perform visual acuity testing. On slit-lamp examination, there was microspherophakia, small inferior subluxation of the lenses, and iridodonesis in both eyes (Figure 1 and 2). The manifest refraction was $-23.75-2.75 \times 70$ in the right eye (OD) and $-25.50-3.50 \times 90$ in the left eye (OS). The mean autokeratometry value of corneal 
curvature was 37.12 D OD and 37.44 D OS. Axial length determined by an immersion A-scan ultrasonography technique was $26.77 \mathrm{~mm}$ OD and $27.54 \mathrm{~mm}$ OS. The anterior chamber depth was $3.03 \mathrm{~mm}$ OD and $2.96 \mathrm{~mm}$ OS. The lens thickness was $4.98 \mathrm{~mm}$ OD and $4.96 \mathrm{~mm}$ OS. Emmetropic intraocular lens $(\mathrm{lOL})$ power calculation using the SRK-T formula was +18.50 D OD and +16.00 D OS (A-constant 118.4). The calculated $\mathrm{IOL}$ power was $+14.00 \mathrm{D}$ for a residual refraction of $+3.00 \mathrm{D}$ OD and $+13.00 \mathrm{D}$ for a residual refraction of $+2.00 \mathrm{D}$ OS.

Because the boy's high myopia compromised his quality of life but he had the potential for good vision in both eyes, clear lens extraction and IOL implantation was suggested. The right eye was operated on first, followed by the left after five months.

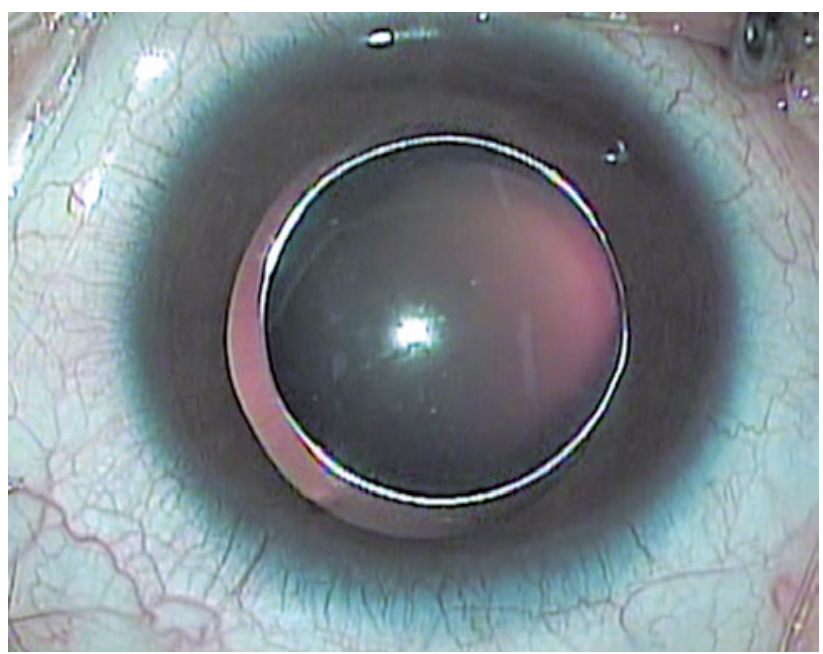

Figure 1. Preoperative photo of the right eye in a 4-year-old boy with Marfan syndrome, microspherophakia and a small subluxation of the lens.

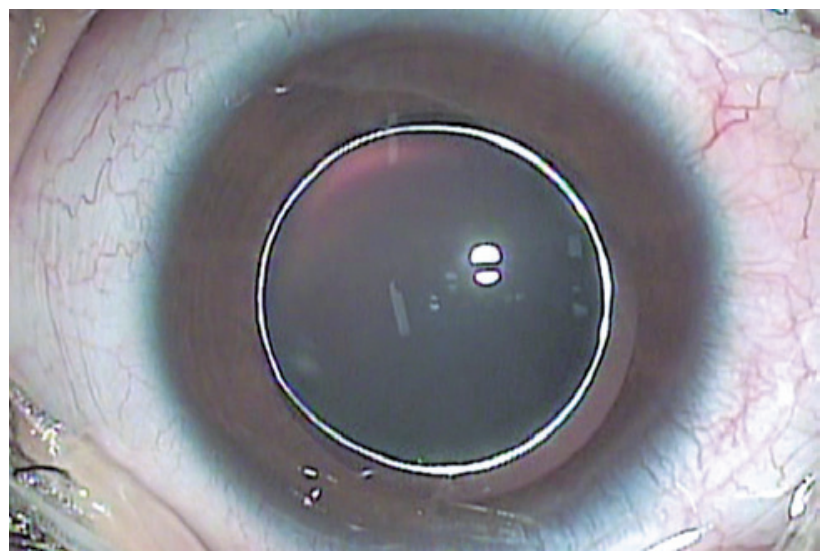

Figure 2. Preoperative photo of the left eye in a 4-year-old boy with Marfan syndrome, microspherophakia and a small subluxation of the lens.
The patient was placed under general anesthesia. Initially, capsulorhexis and phacoaspiration were performed through a superior corneal tunnel made with a crescent-shaped blade and an accessory 15-degree blade incision. A hydrophobic acrylic three-piece $\mathrm{IOL}$ of +14.00 D power Sensar AR40e (Abbott Medical Optics Inc., Santa Ana, CA, USA) was implanted in the capsular bag. The pressure of the lens haptics immediately ovalized the capsular bag. Then, a sclerotomy $3 \mathrm{~mm}$ distant from the limbus was performed, enabling anterior vitrectomy and posterior surgical capsulotomy via

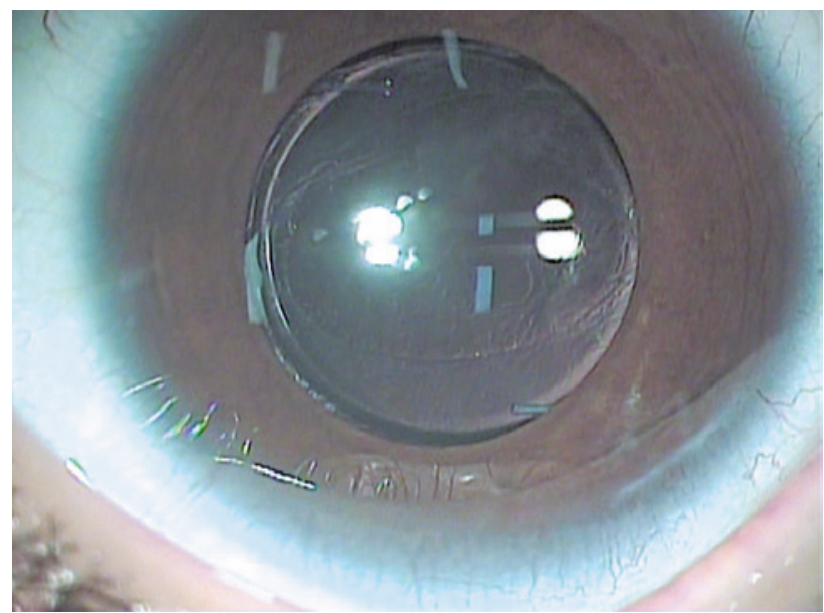

Figure 3. Five months after clear lens extraction and intraocular lens implantation in a 4-year-old boy with Marfan syndrome, microspherophakia and a small subluxation of the lens: anterior biomicroscopy of the right eye.

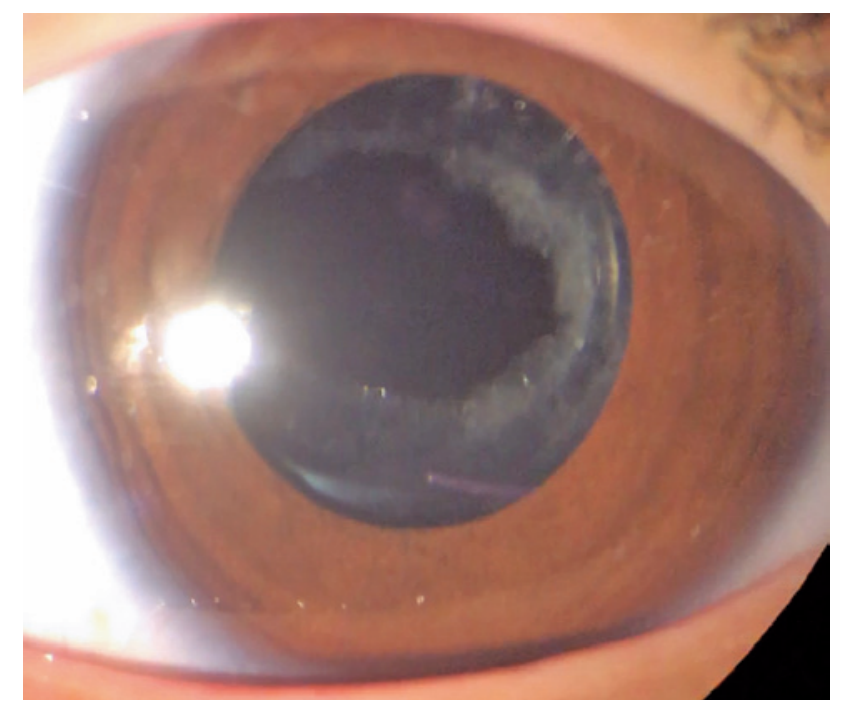

Figure 4. Two years after clear lens extraction and intraocular lens implantation in a 4-year-old boy with Marfan syndrome, microspherophakia and a small subluxation of the lens: anterior biomicroscopy of the right eye. 
the pars plana, maintaining continuous irrigation of the anterior chamber. The same procedure was repeated in the left eye successfully. Figure 3 shows the right eye five months postoperatively.

Two years postoperatively (Figure 4), the patient had centered and stable IOLs, free visual axis, a corrected distance visual acuity of $20 / 30$ in both eyes, and a corrected near visual acuity of $\mathrm{J1}$. The manifest refraction was +2.50-0.75 x 95 OD and +1.50-0.75 x 130 OS; the ADD was +2.25 . The child was satisfied with his vision and was able to study and perform daily activities without any visual limitations.

\section{DISCUSSION}

Clear lens extraction for the purpose of refraction is controversial. However, when microspherophakia is present and the risk of pupillary blockage is high, lens extraction is effective and definitive, yielding important benefits by improving the quality of life of the patient. Studies have shown that refractive lensectomy is effective in improving functional vision in children with high myopia who find it difficult to wear glasses ${ }^{(4,5)}$. The complication rates are low, although posterior capsule regrowth and opacification is common, necessitating secondary membranectomy $y^{(5)}$. In spite of the good results, long-term follow-up and studies with larger sample sizes and controls are still needed to determine the safety of this procedure in pediatric populations ${ }^{(4-6)}$. To avoid subsequent opacification of the posterior capsule requiring a second intervention, the technique used in the present case involved a posterior capsulotomy.

It is worth remembering that in spite of the inherent zonular fragility of the condition in our case, the patient still had a stable IOL bilaterally at his most recent follow-up. The capsular tension ring probably reduces the risk of capsular shrinkage and IOL subluxation and has been described as beneficial in cases of spherophakia ${ }^{(7,8)}$. When zonular weakness is severe, intracapsular lens removal combined with a sulcus-fixated IOL may succeed $^{(9)}$. Schrestha and Pandey ${ }^{(10)}$ described a successful case of clear lens extraction and IOL implantation in the bag without a capsular tension ring in the case of an 11-year-old boy with microspherophakia.

We believe that clear lens extraction and IOL implantation may be a valid treatment option for high myopia in cases of microspherophakia. This approach is also helpful in avoiding sight-threatening complications common in this condition, such as glaucoma and pupillary blockage.

\section{REFERENCES}

1. Duke-Elder S, Cook C. Normal and abnormal development. In: Duke-Elder S, editor. System of ophthalmology. St Louis: Mosby; 1963. p.694-6.

2. Ben Yahia S, Ouechtati F, Jelliti B, Nouira S, Chakroun S, Abdelhak $\mathrm{S}$, et al. Clinical and genetic investigation of isolated microspherophakia in a consanguineous Tunisian family. J Hum Genet. 2009; 54(9):550-3.

3. Senthil S, Rao HL, Hoang NT, Jonnadula GB, Addepalli UK, Mandal $\mathrm{AK}$, et al. Glaucoma in microspherophakia: presenting features and treatment outcomes. J Glaucoma. 2014;23(4):262-7.

4. Tychsen L, Packwood E, Hoekel J, Lueder GT. Refractive surgery for uncorrected high bilateral myopia in children with neurobehavioral disorders: 1 . Clear lens extraction and refractive lens exchange. J AAPOS. 2006;10(4):357-63.

5. Ali A, Packwood E, Lueder G, Tychsen L. Unilateral lens extraction for high anisometropic myopia in children and adolescents. J AAPOS. 2007;11(2):153-8.

6. Paysse EA. Unilateral lens extraction for high anisometropic myopia in children and adolescents: is this prudent? J AAPOS. 2007;11(2): 111-2. Comment in: J AAPOS. 2007;11(2):153-8.

7. Menapace R, Findl O, Georgopoulos M, Rainer G, Vass C, Schmetterer $\mathrm{K}$. The capsular tension ring: designs, applications, and techniques. J Cataract Refract Surg. 2000;26(6):898-912. Comment in: J Cataract Refract Surg. 2002;28(7):1091-2. J Cataract Refract Surg. 2001; 27(3):342-3.

8. Behndig A. Phacoemulsification in spherophakia with corneal touch. J Cataract Refract Surg. 2002;28(1):189-91.

9. Zetterstrom $\mathrm{C}$, Lundvall A, Weeber $\mathrm{H}$ Jr, Jeeves $\mathrm{M}$. Sulcus fixation without capsular support in children. J Cataract Refract Surg. 1999;25(6):776-81. Comment in: J Cataract Refract Surg. 1999; 25(11):1422.

10. Shrestha C, Pandey M. Clear lens extraction with foldable intraocular lens implantation in a case of isolated microspherophakia. Med J Shree Birendra Hosp. 2015;14(2):28-31. 